\title{
Effect of phosphate fertilization on trace element nutrition of Pinus pinaster grown in a sandy acid soil
}

\author{
E. Saur \\ INRA, Station d'Agronomie, C.R.B., 33140 Pont-de-la-Maye, France
}

\section{Introduction}

In the past 30 years, phosphate fertilization has been widely used by foresters in Landes de Gascogne. During this same period, several growth disturbances and malformations without pathological affections have appeared in pines and particularly in $3 \mathrm{yr}$ old pines (twisting of branches and leaders, abundant fascicle shoots, loss of apical dominance, die-back of the top and production of unlignified tissues). The symptoms are similar to those described for other coniferous species in copper- or boron-deficiency conditions. The similarity of the symptoms and the very low trace-element contents in these sandy acid soils were consistent with a possible problem of micronutrient nutrition.

Consequently, we chose to study copper and boron, in addition to zinc and manganese, known or suspected to be involved in deficiency in agricultural plants grown on the same soil. The aim of this study was to evaluate the consequence of phosphate fertilization on the uptake of these 4 main trace elements. This paper reports 3 experiments in which all the trees were grown on the same sandy acid soil with a high organic matter content: 1) seedlings ( 6 mo old) under greenhouse conditions; 2) juveniles (3 yr old) under field conditions; 3) adults (24 yr old) under field conditions.

Manganese, zinc, boron, copper and phosphorus were measured in leaves (adult and juvenile) or in shoots (seedling), as indicators of the nutritional status.

\section{Materials and Methods}

\section{Experiments}

\section{Seedlings ( 6 mo old)}

4 treatments were replicated 5 times: control 150,300 and $750 \mathrm{~kg}^{-h^{-1}} \mathrm{P}_{2} \mathrm{O}_{5}$ triple superphosphate, (hectare was considered as $3 \times 10^{6}$ $\mathrm{kg}$ of soil to accommodate the pot study). Each replicate consisted of $3.5 \mathrm{~kg}$ of soil potted in a 5 I plastic pot with 3 seedlings. Shoots were collected in October 1987.

Juvenile pines ( 3 yr old)

3 treatments were replicated 3 times in a randomized bloc: control, 60 and $120 \mathrm{~kg} \cdot \mathrm{ha}^{-1}$ $\mathrm{P}_{2} \mathrm{O}_{5}$ (triple superphosphate). Leaves were col- 
lected in February 1987 from 10 trees for each treatment.

\section{Adult pines (24 yr old)}

2 treatments were replicated 3 times in a randomized bloc: control and $228 \mathrm{~kg} \cdot \mathrm{ha}^{-1} \mathrm{P}_{2} \mathrm{O}_{5}$ (25 g/m² slag on sowed strips ( $4 \mathrm{~m}$ wide) in $1963 ; 20 \mathrm{~g} / \mathrm{m}^{2}$ phosphate rock on the space between strips ( $3 \mathrm{~m}$ wide) in 1974). Leaves were collected in December 1986 from 10 trees for each treatment.

\section{Chemical analyses}

Protocols were those described in Saur (1989).

\section{Statistical analyses}

Student's $t$-test as modified by Bonferroni was used to compare means concerning seedlings and juveniles (Bachacou et al., 1981). Adult element contents could not be statistically analyzed because only composite samples (representative of the replications comprising a treatment) of the leaves were analyzed chemically.

\section{Results and Discussion}

Analytical results showed the main characteristics of the soil used in the pot ex- periment and bore out the poverty of sandy acid soil: $\mathrm{pH}=4$; organic matter $=$ $9.3 \%$; $P$ (citric acid $2 \%$ ) $=28 \mathrm{mg}$; Cu total $=2.4 \mathrm{mg} ; \mathrm{B}$ total $=1.2 \mathrm{mg} ; \mathrm{Zn}$ total $=8.6$ $\mathrm{mg}$ and $\mathrm{Mn}$ total $=10.8 \mathrm{mg} \cdot \mathrm{kg}^{-1} \mathrm{DW}$.

Table I shows that micronutrient concentrations decrease substantially with the increasing age of the trees. Phosphate fertilization produced a statistically significant effect on trace element contents, except on juvenile boron contents. These effects cannot be due to trace element pollution by triple superphosphate or phosphate rock containing less than 100 $\mathrm{mg} / \mathrm{kg} \mathrm{Mn}, \mathrm{Cu}, \mathrm{B}$ and $1000 \mathrm{mg} / \mathrm{kg} \mathrm{Zn}$ (Swaine, 1962; Juste, personal communication). Moreover, soil analysis showed no consistent differences in micronutrient concentration attributable to the phosphate fertilization in both experiments with seedlings and juveniles. In the adult experiment, $\mathrm{Mn}$ pollution by slag (containing $1.7 \% \mathrm{Mn}$; Juste, personal communication) was not measured in soil; consequently, variation in micronutrient levels in adult leaves should be considered as the result of comon P-fertilization but not as an interaction with P-nutrition. Root examination did not reveal differences in mycorrhizal

Table I. Trace element levels in leaves (adult and juvenile) and in shoots (seedlings).

\begin{tabular}{|c|c|c|c|c|c|c|}
\hline & $\begin{array}{l}\mathrm{P}_{2} \mathrm{O}_{5} \\
\left(\mathrm{~kg} \cdot \mathrm{ha} \mathrm{a}^{-1}\right)\end{array}$ & $\% P$ & $\mathrm{Cu}$ & $\begin{array}{l}B \\
(m g\end{array}$ & $v^{Z n}$ & $M n$ \\
\hline Seedlings & $\begin{array}{r}0 \\
150 \\
300 \\
750\end{array}$ & $\begin{array}{l}0.09 a \\
0.17 a b \\
0.53 b \\
1.09 c\end{array}$ & $\begin{array}{l}6.0 d \\
4.6 c \\
2.6 a b \\
2.0 a\end{array}$ & $\begin{array}{l}33 c \\
36 c \\
26 b \\
12 a\end{array}$ & $\begin{array}{l}63 a \\
76 b \\
80 b c \\
87 c\end{array}$ & $\begin{array}{l}364 a \\
409 a \\
547 b \\
549 b\end{array}$ \\
\hline Juveniles & $\begin{array}{r}0 \\
60 \\
120\end{array}$ & $\begin{array}{l}0.11 a \\
0.14 b \\
0.15 b\end{array}$ & $\begin{array}{l}5.0 \mathrm{~b} \\
4.0 \mathrm{~b} \\
2.0 \mathrm{a}\end{array}$ & $\begin{array}{l}15 a \\
14 a \\
14 a\end{array}$ & $\begin{array}{l}58 b \\
44 a \\
38 a\end{array}$ & $\begin{array}{l}266 b \\
232 b \\
171 a\end{array}$ \\
\hline Adults & $\begin{array}{r}0 \\
228\end{array}$ & $\begin{array}{l}0.06 \\
0.08\end{array}$ & $\begin{array}{l}3.3 \\
3.0\end{array}$ & $\begin{array}{l}17 \\
15\end{array}$ & $\begin{array}{l}30 \\
27\end{array}$ & $\begin{array}{l}67 \\
82\end{array}$ \\
\hline
\end{tabular}

Within each column, means followed by different letters differ significantly at a confidence level of $5 \%$. 
Table II. Bioelement contents in seedlings shoots.

\begin{tabular}{ccccc}
\hline $\begin{array}{c}\mathrm{P}_{2} \mathrm{O}_{5} \\
\left(\mathrm{~kg} \cdot \mathrm{ha}^{-1}\right)\end{array}$ & $\mathrm{Cu}$ & \multicolumn{2}{c}{$\mathrm{B}\left(\mu \mathrm{g} \cdot \mathrm{plant^{-1 } )}\right.$} & $\mathrm{Zn}$ \\
\hline 0 & $17 \mathrm{~b}$ & $95 \mathrm{~b}$ & $181 \mathrm{a}$ & $1043 \mathrm{a}$ \\
750 & $7 \mathrm{a}$ & $46 \mathrm{a}$ & $324 \mathrm{~b}$ & $2037 \mathrm{~b}$ \\
\hline
\end{tabular}

Within each column, means followed by different letters differ significantly at a $5 \%$ confidence level.

infection as a result of P-fertilization in seedlings.

The presence of phosphate strongly depressed the copper concentrations in seedlings and juveniles, demonstrating an antagonism between $\mathrm{P}$ nutrition and $\mathrm{Cu}$ nutrition. Table II shows that micronutrients- $P$ interactions are not a secondary effect due to the increase of the biomass resulting from $P$ fertilization of seedlings, particularly with copper.

The $\mathrm{Cu}-\mathrm{P}$ antagonism has been described in other species (bean, maize, tomato, orange-seedlings; Bingham, 1963), and occurs in soil because of ionic interactions and in root media where phosphates have a strong tendency to adsorb $\mathrm{Cu}$ (Kabata-Pendias and Pendias, 1984).

Boron concentrations in seedlings decreased as P-fertilization increased. Mortvedt (1968) reported a decrease in soluble boron as a consequence of increased phosphate fertilization, related to the interference of phosphate ions with boron mobility. Barlett and Picarelli (1973) described a competition between $\mathrm{P}$ and $\mathrm{B}$ in the uptake process.

In this study, phosphorus nutrition increased zinc and manganese concentrations in seedlings under greenhouse conditions, whereas a decrease of $\mathrm{Zn}$ and $\mathrm{Mn}$ concentrations was noted in juvenile pines in the field. The $\mathrm{Zn}-\mathrm{P}$ synergism borne out by bioelement contents (Table II) in seedlings under greenhouse conditions contrast with common observations.

\section{Conclusion}

$\mathrm{P}-\mathrm{Zn}$ and $\mathrm{P}-\mathrm{Mn}$ synergies in seedlings under greenhouse conditions, in contrast with the antagonisms observed in juvenile pine in the field, obviously show that the results obtained in seedlings under artificial conditions cannot be generalized to tree function under all conditions. Phosphate fertilization decreases $\mathrm{Cu}, \mathrm{Zn}$ and $\mathrm{Mn}$ contents in juveniles in the field; it could be a determinant factor in the advent of micronutrient deficiency, particularly in a poor acid sand. The growth disturbance symptoms brought about by phosphate fertilization in the juvenile stage (3 yr old) could result from copper which decreased down to $2 \mathrm{mg} \cdot \mathrm{kg}^{-1}$ DW when boron remained at a normal physiological level (14 $\left.\mathrm{mg} \cdot \mathrm{kg}^{-1} \mathrm{DW}\right)$.

\section{References}

Bachacou J., Masson J.P. \& Millier C. (1981) In: Manuel de la programmathèque Amance. Service de documentation INRA, 516 
Barlett R.J. \& Picarelli C.J. (1973) Availability of boron and phosphorus as affected by liming and acid potato soil. Soil Sci. 166, 77

Bingham F.T. (1963) Relation between phosphorus and micronutrient in plants. Soil Sci. Soc. Am. Proc. 27, 389-391

Kabata-Pendias A. \& Pendias H. (1984) In: Trace Elements in Soils and Plants. C.R.C. Press, Boca Raton, FL, p. 15
Mortvedt J.J. (1968) Availability of boron in various boronated fertilizers. Soil Sci. Soc. Am. Proc. 32, 433-437

Saur E. (1989) Alimentation oligo-minérale du pin maritime en relation avec quelques caractéristiques physio-chimiques des sols sableux des Landes de Gascogne. Ann. Sci.. For. 46, 119-131

Swaine D.J. (1962) In: The Trace Elements Content of Fertilizers. Technical communication no. $52, \mathrm{CAB}$, p. 306 